\title{
INOVASI PEMBELAJARAN MENULIS KREATIF BERBASIS ICT MELALUI WEB BASED LEARNING DI STKIP YAPIM MAROS; STUDI EKSPERIMEN DAN PENGEMBANGAN MATA KULIAH MENULIS
}

\author{
Syahruddin ${ }^{1}$ dan Abdul Haliq ${ }^{2}$ \\ ( ${ }^{1}$ Dosen STKIP YAPIM Maros dan ${ }^{2}$ Dosen FBS Universitas Negeri Makassar)
}

\begin{abstract}
This study aims to find new innovative teaching creative writing based ICT (Information and Communication Technology) by WBL (Web Based Learning) to improve student writing competence in STKIP Yapim Maros. The design of the study conducted experimental studies and development. Data collection methods used questionnaire, observation formats, and tests for work. Initial test results showed creative writing skills are below the minimum of 70 respondents ie $31(86 \%)$ and only 5 respondents $(14 \%)$ which is above the minimum value of skills. Test to work after treatment showed all respondents $(100 \%)$ is above the minimum value of writing skills. Thus, this study proves that by using ICT media through WBL in writing courses can increase student competency creative writing.
\end{abstract}

Keywords: learning, creative writing, ICT-WBL

Abstrak: Penelitian ini bertujuan menemukan inovasi baru pembelajaran menulis kreatif berbasis ICT (Information and Communication Technology) melalui WBL (Web Based Learning) dalam meningkatkan kompetensi menulis pada mahasiswa STKIP Yapim Maros. Rancangan penelitian dilakukan studi eksperimen dan pengembangan.Metode pengumpulan data digunakan penyebaran angket, format observasi, dan tes unjuk kerja. Hasil penelitianmenunjukkan tes awal keterampilan menulis kreatif berada di bawah nilai minimal 70 yaitu 31 responden (86\%) dan hanya 5 responden (14\%) yang berada di atas nilai keterampilan minimal. Tes unjuk kerja sesudah perlakuan menunjukkan semua responden $(100 \%)$ berada di atas nilai minimalketerampilan menulis.Penelitian ini membuktikan dengan memanfaatkan media ICT melalui WBL dapat meningkatkan kompetensi mahasiswa menulis kreatif.

Kata Kunci: pembelajaran, menulis kreatif, ICT-WBL

Kemajuan teknologi informasi dan komunikasi dalam bidang pendidikan membuka cakrawala baru bagi pembukaan kesempatan (akses) dan peningkatan mutu pendidikan pada semua jenjang, jalur, dan jenis pendidikan. Pendidikan dengan memanfaatkan sistem pembelajaran secara tatap muka tetap merupakan model utama pendidikan, tetapi model pembelajaran online melalui media internet sudah lama juga berkembang. Pembelajaran online berbasis internet merupakan bagian dari pendidikan jarak jauh (distance education) tercantum di dalam Undang-Undang Republik Indonesia Nomor 20 Tahun 2003 tentang Sistem Pendidikan Nasional. Rumusannya

Makalah ini telah dipresentasikan dan dimuat dalam prosiding pada kegiatan Simposium Internasional Bahasa, Sastra, dan Budaya Indonesia dalam Pengembangan Profesionalisme oleh Jurusan Bahasa dan Sastra Indonesia, FBS Universitas Negeri Makassar yang dilaksanakan Swiss Belinn, Panakkukang - Makassar pada Tanggal 13 - 14 Oktober 2014 
terdapat pada pasal 31 ayat 1 yang berbunyi: Pendidikan jarak jauh diselenggarakan pada semua jalur, jenjang, dan jenis pendidikan (Munir, 2009).

Sudah selayaknya lembaga-lembaga pendidikan yang ada segera memperkenalkan dan memulai penggunaan ICT(Information and Communication Technology) melalui WBL (Web Based Learning) sebagai basis pembelajaran yang lebih mutakhir. Hal ini menjadi penting, mengingat penggunaan ICT merupakan salah satu unsur penting yang memungkinkan kecepatan transformasi ilmu pengetahuan kepada para siswa secara lebih luas. Dalam konteks yang lebih spesifik, Isjoni (2007) mengatakan bahwa kebijakan penyelenggaraan pendidikan, baik yang diselenggarakan oleh pemerintah pusat, pemerintah daerah, maupun masyarakat harus mampu memberikan akses pemahaman dan penguasaan teknologi mutakhir yang luas kepada para siswa.

Berdasarkan pengamatan, guru/dosen di kelas jarang memanfaatkan fungsi media pembelajaran secara optimal. Kondisi ini disebabkan oleh kenyataan bahwa tugas yang diemban guru sebagai perancang pembelajaran adalah sangat rumit, karena berhadapan dengan dua variabel di luar kontrolnya, yaitu (1) cakupan isi pembelajaran yang telah ditetapkan terlebih dahulu berdasarkan tujuan yang akan dicapai, dan (2) siswa/mahasiswa yang membawa seperangkat sikap, kemampuan awal, dan karakteristik perseorangan lainnya ke dalam situasi pembelajaran.

Arsyad (2006) mengemukakan bahwa pemakaian media pembelajaran dalam proses belajar mengajar dapat membangkitkan keinginan dan minat yang baru, motivasi, dan rangsangan kegiatan pembelajaran dan bahkan membawa pengaruhpengaruh psikologis terhadap siswa. Penggunaan media pembelajaran akan sangat membantu efektivitas proses pembelajaran serta penyampaian pesan dan isi pelajaran untuk meningkatkan pemahaman siswa dalam menyajikan informasi secara menarik dan terpercaya. Selain itu, media pembelajaran juga dapat memudahkan penafsiran data dan memadatkan informasi. Hal ini memungkinkan tercapainya tujuan pembelajaran, yang pada akhirnya dapat meningkatkan proses dan hasil belajar.

Pemanfaatan media ICT dalam pembelajaran di sekolah merupakan suatu hal yang inovatif dan kreatif dalam pengajaran. Hal ini merupakan bagian dari e-learning yang tergolong baru dan aktual dalam khasanah perkembangan ilmu pengetahuan. Jaringan teknologi informasi dan komunikasi ke sekolah-sekolah dan perguriuan tinggi sudah gencar dilaksanakan oleh pemerintah dalam sistem jardiknas. Dengan demikian, tujuan penelitian ini secara umum dapat dirumuskan sebagai berikut: untuk menemukan inovasi pembelajaran bahasa Indonesia berbasis ICT melalui web based learning terhadap peningkatan kompetensi menulis kreatif Mahasiswa STKIPYapim Maros.

\section{METODE PENELITIAN}

Kegiatan penelitian ini dilakukan melalui enam tahap, yaitu: (1) melakukan analisis kebutuhan, (2) mengembangkan desain pembelajaran, (3) mengembangkan media WBL, (4) melakukan validasi ahli, (5) melakukan uji coba, dan (6) kajian/analisis data primer dan sekunder. Di samping itu, fokus penelitian ini adalah penggunaan media ICT melalui WBL, aktivitas mahasiswa dalam pembelajaran, dan kompetensi mahasiswa dalam menulis kreatif. 


\section{Lokasi Penelitian}

Penelitian ini berlokasi di STKIP Yapim Maros yang sudah menggunakan jaringan internet dengan program Lokal Area Network (LAN). STKIP Yapim Maros sudah menerapkan pembelajaran menulis berbasis ICT.

\section{Populasi dan Sampel}

Populasi penelitian ini berjumlah 323 orang dan sampel penelitian adalah 72 mahasiswa atau $22,3 \%$ dari jumlah populasi. Berdasarkan populasi yang ada, maka peneliti melakukan pengambilan sampel dengan menggunakan teknik cluster ramdom sampling. Teknik ini dianggap cocok dengan karakteristik yang dimiliki oleh populasi penelitian ini. Dengan teknik cluster random sampling dipilih dua kelas masingmasing satu kelas sebagai sampel kelompok eksperimen dan satu kelas sebagai kelompok kontrol. Jumlah sampel setiap kelas adalah 36 siswa masing-masing pada kelas eksperimen dan kelas kontrol.

\section{Pengumpulan Data}

Penelitian ini merupakan penelitian eksperimen yang mengungkapkan hubungan sebab akibat dilakukan terhadap program, kegiatan atau kejadian yang telah berlangsung atau telah terjadi. Dengan demikian, penelitian ini dilakukan dengan menggunakan kelompok eksperimen dan kelompok pembanding (kontrol). Kelompok pembanding dipilih yang memiliki karakteristik yang sama tetapi melakukan kegiatan, program, atau mengalami kejadian yang berbeda (Sukmadinata, 2008).

Variabel penelitian ini ada dua, yaitu variabel terikat dan variable bebas. Variabel terikat penelitian ini ialah hasil belajar atau kompetensi menulis yang dilambangkan dengan "Y". Kompetensi yang dimaksudkan dilihat dari kemampuan mahasiswa dalam menulis kreatif yang meliputi: (1) alur tulisan meliputi informasi yang lengkap cermat, dan relevan dengan judul; (2) paparan isi tulisan yang jelas sehingga menggugah pikiran, logis, dan sistematis; dan (3) penggunaan bahasa Indonesia dengan struktur, gaya bahasa, dan kaidah bahasa yang baik dan benar. Sedangkan, variable bebas penelitian ini ialah pembelajaran menulis berbasis ICT melalui WBL yang dilambangkan dengan "X". Adapun sebagai pengendali terhadap perlakuan tersebut digunakan pembelajaran menulis tanpa ICT yang diberikan kepada kelompok kontrol.

\section{Analisis Data}

Instrumen penelitian digunakan adalah angket, format observasi, dan tes unjuk kerja. Adapun teknik analisis datadigunakan teknik statistik deskriptif dan statistik inferensial uji beda jenis ANOVA.Uji persyaratan analisis dilakukan dengan menggunakan uji normalitas data dan program komputer SPSS 15.0 for Windows dengan penghitungan model lilliefors (Kolmogorov-Smirnov) dan Shapiro-Wilks. Dengan ketentuan, jika P > 0,05, maka hipotesis nol (H0) diterima. Artinya, data yang diperoleh dinyatakan normal. Sebaliknya, jika $\mathrm{P}<0,05$, maka Ho dinyatakan ditolak. Artinya, data atau sebaran skor variabel penelitian dinyatakan tidak normal. 


\section{HASIL PENELITIAN}

\section{Desain Pembelajaran Berbasis ICT melalui WBL}

Data validasi desain pembelajaran berbasis ICT melalui web based learning terdiri atas garis besar program pembelajaran (GBPP), bahan ajar online, dan media web based learning. Nilai rata-rata total kevalidan GBPP diperoleh adalah $\bar{V}=3,6$, dapat disimpulkan bahwa nilai ini termasuk dalam kategori "Sangat Valid" $(3,5 \leq \bar{V}$ <4). Selanjutnya, nilai rata-rata total kevalidan bahan ajar online adalah $\bar{V}=3,6$, dapat disimpulkan bahwa nilai ini termasuk dalam kategori "Sangat Valid" $(3,5 \leq \bar{V}$ $\leq 4)$. Nilai rata-rata total kevalidan media web based learning adalah $\bar{V}=3,7$, dapat disimpulkan bahwa nilai ini termasuk dalam kategori "Sangat Valid" $(3,5 \leq \bar{V} \leq 4)$. Jadi, ditinjau keseluruhan aspek pada GBPP, bahan ajar online, dan media WBL ini dinyatakan memenuhi kriteria kevalidan.

Dengan hasil-hasil tersebut di atas, disimpulkan bahwa desain pembelajaran menulis kreatif bahasa Indonesia dalam penelitian ini layak digunakan. Hal ini dapat diketahui bahwa semua aspek desain pembelajaran memiliki kategori "Sangat Valid" $(3,5 \leq \bar{V} \leq 4)$.

Total nilai tes kesiapan menulis dalam pembelajaran keterampilan menulis kreatif dengan menggunakan media web based learning pada mahasiswa kelas bahasa I yaitu di antara 36 responden terdapat 27 responden $(75,0 \%)$ memperoleh nilai sangat tinggi, terdapat 7 responden $(19,4 \%)$ memperoleh nilai kategori tinggi, 2 responden $(5,6 \%)$ memperoleh nilai sedang, dan tidak ada satu pun responden memperoleh nilai kategori rendah dan sangat rendah. Nilai rata-rata tes kesiapan menulis kreatif melalui web yang diperoleh mahasiswa sebesar 90,6. Artinya, tingkat rata-rata nilai tes kesiapan menulis mahasiswa berbasis ICT berada pada kategori sangat tinggi. Hal ini membuktikan bahwa mahasiswa kelas bahasa I (kelas eksperimen) sudah dapat mengoperasikan media web based learning dalam pembelajaran.

\section{Peningkatan Kompetensi Menulis Kreatif melalui WBL}

Kompetensi menulis kreatifmahasiswa dilihat pada tiga kompetensi yaknialur tulisan, kemampuan memaparkan ide dalam tulisan, dan penggunaan bahasa sesuai kaidah bahasa Indonesia yang baik dan benar.

Hasil penelitian menunjukkan bahwa kompetensi mahasiswa menulis kreatif pada pada tes awal dan tes akhir mengalami peningkatan. Hal ini diketahui dengan memperhatikan hasil statistiknya. Pada tes awal rata-rata kompetensi mahasiswa menulis kreatif adalah 57,0 dan pada tes akhir rata-rata hasil belajarnya 90,0. Hal ini menunjukkan bahwa hasil belajar mahasiswa mengalami peningkatan jika ditinjau dari rata-rata hasil belajar mahasiswa.

Ketercapaian hasil belajar dari tes awal ke tes akhir mengalami peningkatan, hal ini diketahui bahwa pada tes awal mahasiswa, ketercapaian hasil belajar mahasiswa hanya 5,6\% dan pada tes akhir ketercapaian hasil belajarnya $100 \%$. Artinya bahwa mahasiswa sudah memiliki ketercapaian belajarnya di atas $85 \%$ yang memperoleh nilai minimal 70 sesuai dengan kriteria ketercapaian minimal pembelajaran. Hal ini membuktikan bahwa ada peningkatan hasil belajar mahasiswa 
pada kompetensi menulis kreatif berbasis ICT melalui WBL. Berikut ini ditampilkan tabel peningkatan menulis kreatif berbasis ICT (PMK BICT).

Tabel 1. Frekuensi Total Nilai PMK BICT

\begin{tabular}{|c|c|c|l|}
\hline Interval Kelas & Frekuensi & Persentase (\%) & \multicolumn{1}{|c|}{ Kategori } \\
\hline $90,0-100$ & 26 & $72,2 \%$ & Sangat tinggi \\
\hline $80,0-89,9$ & 8 & $22,2 \%$ & Tinggi \\
\hline $70,0-79,9$ & 2 & $5,6 \%$ & Sedang \\
\hline $55,0-69,9$ & 0 & $0 \%$ & Rendah \\
\hline $0-54,9$ & 0 & 0 & Sangat rendah \\
\hline Jumlah & 36 & $100 \%$ & \\
\hline
\end{tabular}

Apabila diilustrasikan ke dalam diagram batang, frekuensi total nilai tes unjuk kerja kompetensi menulis kreatif melalui web pada mahasiswa kelas bahasa I, tampak seperti berikut ini.

\section{Kelas Eksperimen \\ PMK BICT}

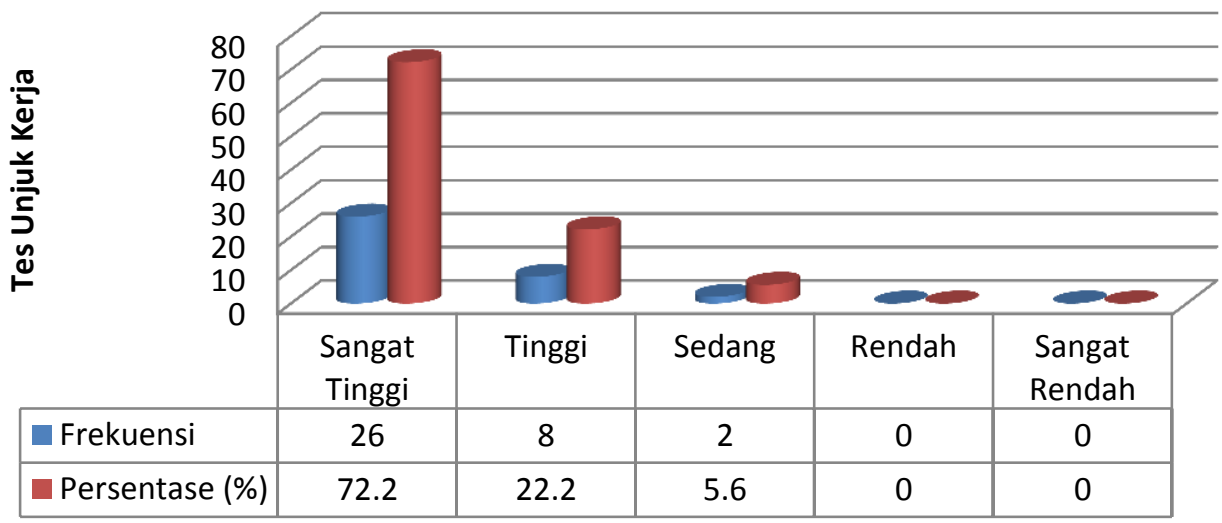

Aktivitas Mahasiswa dalam Pembelajaran Menulis Kreatif Berbasis ICT

Instrumen yang digunakan untuk mengungkap tingkat aktivitas mahasiswa dalam pembelajaran terdiri atas tujuh butir aktivitas yaitu (1) mengikuti kegiatan belajar sesuai dengan arahan dosen, (2) mengembangkan inisiatif menulis, (3) keberanian bertanya atau mengemukakan pendapat secara lisan dan tertulis, (4) melaksanakan kegiatan untuk pendalaman materi, (5) melakukan eksperimen atau mengembangkan kegiatan menulis, (6) berkomunikasi secara akrab dengan dosen, dan (7) bekerja sama dengan teman lain. Kegiatan aktivitas mahasiswa diungkapkan dalam kelas eksperimen dan kelas kontrol.

Hasil rekapitulasi aktivitas mahasiswa dalam pembelajaran menulis kreatif berbasis ICT dapat dilihat pada tabel berikut ini.

Tabel 2. Rekapitulasi Aktivitas Kegiatan Menulis Kreatif

\begin{tabular}{|l|l|c|c|c|c|}
\hline \multirow{2}{*}{ No } & \multicolumn{1}{|c|}{ Jenis Kegiatan } & \multicolumn{2}{c|}{ Kelas Eksperimen } & \multicolumn{2}{c|}{ Kelas Kontrol } \\
\cline { 3 - 6 } & \multicolumn{1}{|c|}{ Skor } & \% & Skor & $\%$ \\
\hline 1. & $\begin{array}{l}\text { Mengikuti kegiatan belajar sesuai } \\
\text { dengan arahan dosen. }\end{array}$ & 101 & $93,5 \%$ & 98 & $90,7 \%$ \\
\hline 2. & Mengembangkan inisiatif menulis. & 104 & $96,3 \%$ & 69 & $63,9 \%$ \\
\hline
\end{tabular}




\begin{tabular}{|l|l|c|c|c|c|}
\hline 3. & $\begin{array}{l}\text { Keberanian bertanya atau } \\
\text { mengemukakan pendapat secara } \\
\text { lisan dan tertulis. }\end{array}$ & 93 & $86,1 \%$ & 80 & $74,1 \%$ \\
\hline 4. & $\begin{array}{l}\text { Melaksanakan kegiatan untuk } \\
\text { pendalaman materi. }\end{array}$ & 89 & $82,4 \%$ & 77 & $71,3 \%$ \\
\hline 5. & $\begin{array}{l}\text { Melakukan eksperimen atau } \\
\text { mengembangkan kegiatan menulis. }\end{array}$ & 102 & $94,4 \%$ & 64 & $59,3 \%$ \\
\hline 6. & $\begin{array}{l}\text { Berkomunikasi secara akrab } \\
\text { dengan dosen. }\end{array}$ & 95 & $88,0 \%$ & 89 & $82,4 \%$ \\
\hline 7. & Bekerja sama dengan teman lain. & 86 & $79,6 \%$ & 91 & $84,3 \%$ \\
\hline & Rata-rata & $\mathbf{9 5 , 7}$ & $\mathbf{8 8 , 4 \%}$ & $\mathbf{8 1 , \mathbf { 1 }}$ & $\mathbf{7 5 , \mathbf { 1 \% }}$ \\
\hline
\end{tabular}

Apabila diilustrasikan ke dalam grafik, frekuensi total nilai aktivitas siswa dalam kegiatan pembelajaran kelas eksperimen dan kelas kontrol tampak seperti berikut ini.

Efektivitas Model Pembelajaran Menulis Kreatif Berbasis ICT

Instrumen yang digunakan dalam mengungkapkan efektivitas model

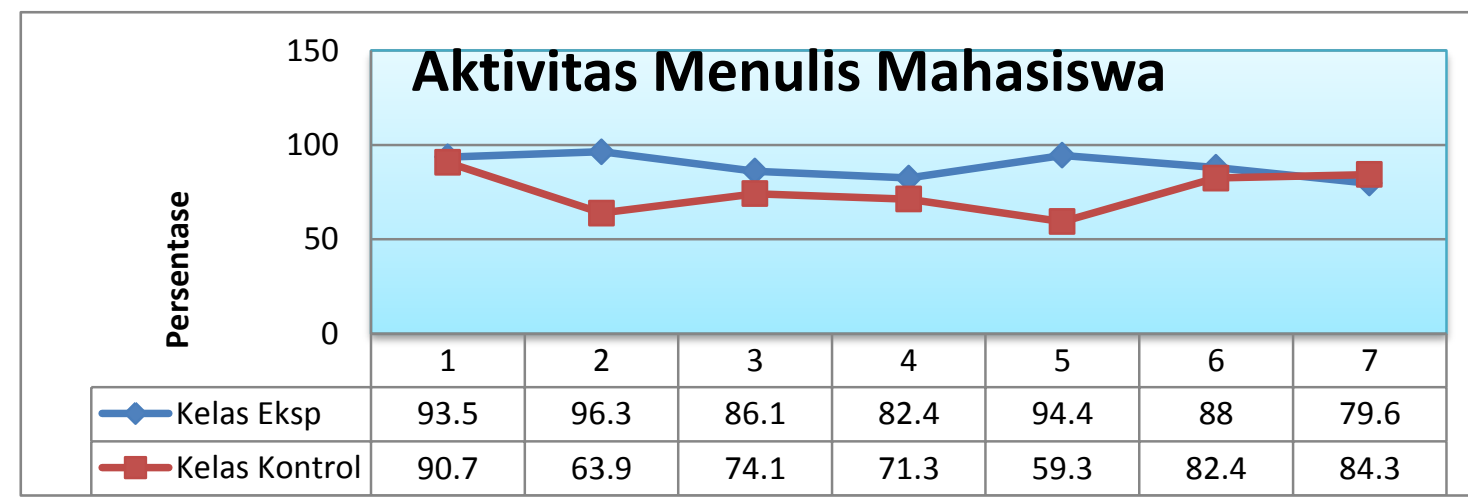

pembelajaran menulis kreatif berbasis ICT melalui web based learningadalah angket yang terdiri atas 9 item pertanyaan. Kesembilan item pertanyaan tersebut didasarkan pada 9 prinsip integrasi ICT dalam pembelajaran yakni aktif, konstruktif, kolaboratif, antusiastik, interaktif, kontekstual, reflektif, multisensory, dan melatih kemampuan berpikir tingkat tinggi. Angket yang diberikan kepada siswa diolah dengan cara skala liekert dengan analisis persentase. Kriteria keefektifan apabila jumlah responden $\geq$ $50 \%$ menjawab sangat setuju atau setuju, maka pembelajaran sudah efektif, dan apabila sebaliknya jumlah responden $<50 \%$ menjawab sangat setuju atau setuju, maka pembelajaran tidak efektif. Pendapat mahasiswa dalam angket tentang efektivitas model pembelajaran menulis kreatif berbasis ICT diuraikan pada penjelasan berikut ini.

Tabel 3. Keefektifan Model Pembelajaran Menulis Kreatif Berbasis ICT

\begin{tabular}{|c|c|c|c|c|c|c|c|c|c|c|c|c|}
\hline \multirow{3}{*}{ No } & \multirow{3}{*}{$\begin{array}{c}\text { Keefektifan } \\
\text { Pembelajaran }\end{array}$} & \multicolumn{10}{|c|}{ Pernyataan } & \multirow{3}{*}{ Ket. } \\
\hline & & \multicolumn{2}{|c|}{ SS } & \multicolumn{2}{|c|}{$\mathrm{S}$} & \multicolumn{2}{|c|}{ TS } & \multicolumn{2}{|c|}{ STS } & \multicolumn{2}{|c|}{ TB } & \\
\hline & & $\mathrm{F}$ & $\%$ & $\mathrm{~F}$ & $\%$ & $\mathrm{~F}$ & $\%$ & $\mathrm{~F}$ & $\%$ & $\mathrm{~F}$ & $\%$ & \\
\hline 1. & Aktif & 25 & 69,4 & 10 & 27,8 & 1 & 2,8 & 0 & 0 & 0 & 0 & Efektif \\
\hline 2. & Konstruktif & 23 & 63,8 & 11 & 30,6 & 2 & 5,6 & 0 & 0 & 0 & 0 & Efektif \\
\hline 3. & Kolaboratif & 26 & 72,2 & 8 & 22,2 & 2 & 5,6 & 0 & 0 & 0 & 0 & Efektif \\
\hline 4. & Antusiastik & 20 & 55,6 & 12 & 33,3 & 1 & 2,8 & 3 & 8,3 & 0 & 0 & Efektif \\
\hline
\end{tabular}




\begin{tabular}{|l|l|l|l|l|l|l|l|l|l|l|l|l|}
\hline 5. & Interaktif & 30 & 83,3 & 6 & 16,7 & 0 & 0 & 0 & 0 & 0 & 0 & Efektif \\
\hline 6. & Kontekstual & 19 & 52,8 & 12 & 33,3 & 2 & 5,6 & 0 & 0 & 0 & 0 & Efektif \\
\hline 7. & Reflektif & 25 & 69,4 & 11 & 30,6 & 0 & 0 & 0 & 0 & 0 & 0 & Efektif \\
\hline 8. & Multisensori & 21 & 58,4 & 12 & 33,3 & 3 & 8,3 & 0 & 0 & 0 & 0 & Efektif \\
\hline 9. & $\begin{array}{l}\text { Melatih } \\
\text { kemampuan } \\
\text { berpikir tingkat } \\
\text { tinggi }\end{array}$ & 20 & 55,6 & 8 & 22,2 & 3 & 8,3 & 4 & 11,1 & 1 & 2,8 & Efektif \\
\hline
\end{tabular}

Keterangan:

$\begin{array}{lll}\text { SS }= & \text { Sangat Setuju } \\ \text { S } & = & \text { Setuju } \\ \text { TS } & = & \text { Tidak Setuju } \\ \text { STS } & = & \text { Sangat Tidak Setuju } \\ \text { TB } & = & \text { Tidak Berpendapat } \\ \text { F } & = & \text { Frekuensi } \\ \% & = & \text { Persentase }\end{array}$

Berdasarkan tabel 3 di atas menunjukkan bahwa kesembilan sasaran ICT dalam pembelajaran, semuanya dinyatakan efektif. Dengan demikian bahwa terdapat efektivitas model pembelajaran menulis kreatif berbasis ICT melalui web based learning.

\section{Perbedaan Hasil Belajar Menulis Kreatif}

Hipotesis dalam penelitian ini adalah terdapat perbedaan hasil belajar mahasiswa dalam pembelajaran menulis kreatif berbasis ICT melalui web based learning dengan pembelajaran menulis kreatif tanpa web based learning. Hipotesis penelitian dirumuskan dengan hipotesis nol $\left(\mathrm{H}_{0}\right)$ dan diikuti dengan hipotesis satu $\left(\mathrm{H}_{1}\right)$.

$\mathrm{H}_{0}$ : Tidak ada perbedaan secara signifikan antara hasil belajar menulis kreatif berbasis ICT melalui web based learning dengan hasil belajar menulis kreatif tanpa web based learning.

$\mathrm{H}_{1}$ : Tidak ada perbedaan secara signifikan antara hasil belajar menulis kreatif berbasis ICT melalui web based learning dengan hasil belajar menulis kreatif tanpa web based learning.

$$
\mathrm{H}_{0}: \mu_{1}=\mu_{2} \text { vs } \mathrm{H}_{1}: \mu_{1} \neq \mu_{2}
$$

Pengujian dilakukan dengan taraf signifikan 5\%

Tabel 4. Hasil Uji t

\begin{tabular}{|c|c|c|c|c|c|c|c|c|c|c|}
\hline & \multicolumn{2}{|c|}{$\begin{array}{l}\text { Levene's Test for } \\
\text { Equality of } \\
\text { Variances }\end{array}$} & \multicolumn{7}{|c|}{ t-test for Equality of Means } \\
\hline & & $\mathrm{F}$ & Sig. & \multirow{2}{*}{$\begin{array}{c}\mathrm{T} \\
\text { Lower }\end{array}$} & \multirow{2}{*}{$\begin{array}{c}\text { Df } \\
\text { Upper }\end{array}$} & \multirow{2}{*}{$\begin{array}{l}\begin{array}{l}\text { Sig. (2- } \\
\text { tailed) }\end{array} \\
\text { Lower }\end{array}$} & \multirow{2}{*}{$\begin{array}{c}\text { Mean } \\
\text { Difference } \\
\\
\text { Upper }\end{array}$} & \multirow{2}{*}{$\begin{array}{c}\text { Std. Error } \\
\text { Difference } \\
\\
\text { Lower }\end{array}$} & \multicolumn{2}{|c|}{$\begin{array}{l}\text { 95\% Confidence } \\
\text { Interval of the } \\
\text { Difference }\end{array}$} \\
\hline & & Lower & Upper & & & & & & Upper & Lower \\
\hline Nilai & $\begin{array}{l}\text { Equal } \\
\text { variances } \\
\text { assumed } \\
\text { Equal } \\
\text { variances } \\
\text { not }\end{array}$ & .035 & .853 & 5.069 & 69.300 & .000 & 10.38889 & 2.04948 & $\begin{array}{l}6.30133 \\
6.30061\end{array}$ & 14.47644 \\
\hline
\end{tabular}




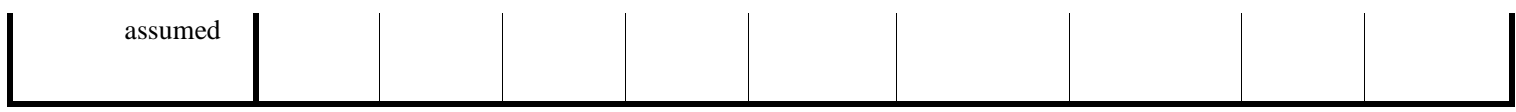

Dari tabel 4 di atas diperoleh nilai $t_{\text {hitung }}=5,069$. Dengan menggunakan tingkat keyakinan 95\%, $\alpha=5 \%$, dan derajat kebebasan 18 diperoleh nilai $t_{\text {tabel }}=2,101$. Hasil analisis menunjukkan $\mathrm{t}_{\text {hitung }}>\mathrm{t}_{\text {tabel }}(5,069>2,101)$ maka $\mathrm{H}_{0}$ ditolak dan $\mathrm{H}_{1}$ diterima. Hal ini berarti bahwa ada perbedaan secara signifikan antara hasil belajar menulis kreatif berbasis ICT melalui web based learning dengan hasil belajar menulis kreatif tanpa web based learning.

\section{PEMBAHASAN}

Pembelajaran keterampilan menulis melalui ICT untuk meningkatkan kompetensi menulis kreatif mahasiswa STKIP Yapim Maros dalam penelitian ini telah dilakukan melalui enam tahap, yaitu (1) melakukan analisis kebutuhan, (2) mengembangkan desain pembelajaran, (3) mengembangkan media web based learning, (4) melakukan validiasi ahli, (5) melakukan uji coba instrumen, dan (6) kajian/analisis data primer dan data sekunder. Di samping itu, fokus penelitian ini adalah efektivitas penggunaan media ICT melalui web based learning, aktivitas mahasiswa dalam pembelajaran, dan kompetensi mahasiswa menulis kreatif.

Instrumen yang digunakan dalam mengungkap persepsi mahasiswa terhadap media ICT adalah angket yang terdiri atas lima butir pertanyaan memuat tentang (1) animasi penampilan web, (2) materi website pembelajaran, (3) pemaparan illustrasi, (4) contoh-contoh dalam materi web, dan (5) Web dijadikan suplemen pembelajaran. Kelima butir pertanyaan ini dinalisis dengan menggunakan skala liekert dengan rentang skala 1 sampai dengan 4 . Nilai 4 berarti sangat menarik, nilai 3 berarti menarik, nilai 2 berarti kurang menarik, dan nilai 1 berarti tidak menarik.

Sesuai analisis data persentase ketertarikan mahasiswa terhadap penggunaan media web dalam pembelajaran keterampilan menulis kreatif adalah sangat menarik $79 \%$, menarik 18\%, dan kurang menarik 3\%. Dengan demikian dapat disimpulkan bahwa web yang digunakan dalam pembelajaran keterampilan menulis kreatif sangat menarik. Kesimpulan ini diambil karena lebih dari setengah jumlah mahasiswa menunjukkan daya tarik produk berada pada kriteria sangat menarik.

Rekapitulasi nilai tes unjuk kerja mahasiswa kelas bahasa I menunjukkan di antara 36 jumlah responden, ada 26 responden $(72,2 \%)$ memperoleh nilai kategori sangat tinggi, 8 responden $(22,2 \%)$ memperoleh nilai tinggi, terdapat 2 responden $(5,6 \%)$ memperoleh nilai sedang, dan tidak seorang pun responden yang memperoleh nilai rendah dan sangat rendah. Hasil analisis statistik deskriptif membuktikan pula bahwa nilai maksimun 95,9, nilai minimun 70,4 , dan nilai rata-rata tes unjuk kerja pada kompetensi menulis kreatif yang diperoleh mahasiswa kelas bahasa I sebesar 90,0. Artinya, tingkat rata-rata nilai pembelajaran menulis kreatif pada mahasiswa kelas bahasa I pada kompetensi menulis kreatif berada pada kategori sangat tinggi.

Aktivitas belajar di kelas eksperimen dan kelas kontrol pada setiap kegiatan bervariasi. Aktivitas kegiatan belajar sesuai dengan arahan dosen pada kelas eksperimen memiliki skor 101 atau 93,5\% dan kelas kontrol memilki skor 98 atau 90,7\%, mengembangkan inisiatif menulis pada kelas eksperimen memiliki skor 104 atau 96,3\% dan kelas kontrol memilki skor 69 atau 63,9\%, keberanian bertanya atau mengemukakan pendapat secara lisan dan tertulis pada kelas eksperimen memiliki skor 93 atau 86,1\% dan kelas kontrol memiliki skor 80 atau 74,1\%, melaksanakan 
kegiatan untuk pendalaman materi pada kelas eksperimen memiliki skor 89 atau $82,4 \%$ dan kelas kontrol memiliki skor 77 atau 71,3\%, melakukan eksperimen atau mengembangkan kegiatan menulis pada kelas eksperimen memiliki skor 102 atau 94,4\% dan kelas kontrol memiliki skor 64 atau 59,3\%, berkomunikasi secara akrab dengan guru pada kelas eksperimen memiliki skor 95 atau 88,0\% dan kelas kontrol memiliki skor 89 atau $82,4 \%$, dan bekerjasama dengan teman lain pada kelas eksperimen memiliki skor 86 atau 79,6\% dan kelas kontrol memiliki skor 91 atau $84,3 \%$. Secara keseluruhan rata-rata tingkat aktivitas belajar siswa pada kelas eksperimen memiliki skor 95,7 atau 88,4\% dengan kategori tinggi dan kelas kontrol memiliki rata-rata skor 81,1 atau $75,1 \%$ dengan kategori sedang.

Media ICT melalui web based learning sangat efektif digunakan dalam pembelajaran menulis kreatif. Keefektifan meodel pembelajaran menulis kreatif berbasis ICT melalui web based learning terlihat pada respon mahasiswa mencakup unsur-unsur berikut ini.

a. Mahasiswa terlibat aktif dalam proses belajar mengajar,

b. Mahasiswa dapat menggabungkan ide-ide baru ke dalam pengetahuan yang telah ia miliki sebelumnya,

c. Mahasiswa dapat saling bekerja sama, berbagi ide, saran, pengalaman, dan memberi masukan untuk sesama anggota kelompok,

d. Mahasiswa secara aktif dan antusias berusaha untuk mencapai tujuan pembelajaran,

e. Mahasiswa dapat mengembangkan proses belajar secara interaktif atau dialogis (proses komunikasi) baik di dalam maupun di luar kelas,

f. Dosen dapat mengembangkan situasi belajar diarahkan pada proses belajar yang bermakna,

g. Mahasiswa dapat memberikan refleksi pada materi yang telah dipelajari sebagai bagian dari proses belajar itu sendiri,

h. Mahasiswa dapat mengikuti pembelajaran yang disampaikan dengan berbagai modalitas belajar baik audio, visual, maupun kinestetik, dan

i. Mahasiswa dapat melatih kemampuan berpikir tingkat tinggi seperti problem solving dan pengambilan keputusan.

Dengan demikian, pembelajaran menulis kreatif melalui web based learning lebih efektif dalam meningkatkan kompetensi menulis kreatif mahasiswa. Kondisi ini disebabkan oleh beberapa hal, yaitu (1) kegiatan belajar lebih menarik dan tidak membosankan sehingga motivasi belajar mahasiswa lebih tinggi, (2) hakikat belajar akan lebih bermakna karena mahasiswa dihadapkan pada situasi dan keadaan yang berbagai modalitas belajar baik audio, visual, maupun kinestetik, (3) bahan-bahan yang dapat dipelajari melalui media web lebih kaya serta lebih faktual sehingga kebenarannya lebih akurat, (4) kegiatan belajar mahasiswa lebih komprehensif dan lebih aktif karena dapat dilakukan dengan berbagai cara, seperti: mengamati, bertanya atau wawancara, menguji fakta, membuktikan atau mendemonstrasikan, dan lain-lain, (5) sumber belajar menjadi lebih kaya, karena media web dapat mengakses beraneka ragam materi pembelajaran sesuai topik yang dinginkan, dan (6) mahasiswa dapat memahami dan menghayati aspek-aspek pengembangan materi pembelajaran sesuai dengan perkembangan teknologi dan informasi masa kini.

Hasil penelitian ini ditemukan ada perbedaan secara signifikan antara nilai tes akhir pembelajaran menulis kreatif melalui web based learning dengan pembelajaran menulis kreatif tanpa web based learning. Di samping itu, hasil penelitian ini 
menunjukkan bahwa kelas eksperimen menggunakan pendekatan berorientasi pada mahasiswa (student centered approaches) dan kelas kontrol menggunakan pendekatan berorientasi pada guru/dosen (teacher centerd approaches). Pendekatan pembelajaran berorientasi pada mahasiswa di kelas eksperimen mengacu pada pendekatan pembelajaran yang menempatkan mahasiswa sebagai subjek belajar yang melahirkan kegiatan belajar bersifat modern dengan media ICT. Melalui web based learning, mahasiswa memiliki kesempatan yang terbuka untuk melakukan kreativitas dan mengembangkan potensinya dengan aktivitas secara langsung sesuai minat dan keinginannya.

Selanjutnya, pembelajaran berbasis ICT melalui web based learning menurunkan strategi pembelajaran discovery dan inquiry serta strategi pembelajaran induktif yakni pembelajaran yang berpusat pada siswa/mahasiswa. Strategi ini peran guru/dosen lebih memaparkan diri sebagai fasilitator dan pembimbing sehingga kegiatan belajar siswa/mahasiswa menjadi lebih terarah.

Temuan penelitian ini menunjukkan bahwa terdapat inovasi pembelajaran menulis kreatif berbasis ICT melalui web based learning dalam meningkatkan hasil belajar. Namun, media ini tidak dapat dipungkiri bahwa selain memiliki kelebihan juga memiliki kekurangan. Adapun kelebihannya adalah (1) mampu mengatasi keterbatasan ruang dan waktu dan memungkinkan menjangkau sasaran yang luas, (2) mampu mengembangkan daya imajinasi mahasiswa, (3) mampu memusatkan perhatian mahasiswa pada penggunaan kata-kata, bunyi, dan arti dari kata/bunyi itu, (4) sangat tepat/cocok untuk mengajarkan bahasa terutama menulis, (5) mampu mempengaruhi suasana dan perilaku siswa melalui latar audiovisual website, (6) dapat dijadikan portofolio dalam menyimpang tugas-tugas siswa/mahasiswa, dan (7) guru/dosen dapat menyajikan program pendalaman materi melalui web sehingga materi yang dibahas bermutu.

Di samping kelebihan di atas, media web pun memiliki keterbatasan atau kekurangan. Kekurangan media web yang mencolok adalah sifat komunikasinya hanya satu arah dan susah mengembangkan diskusi atau bekerjasama dengan mahasiswa lain dalam pembelajaran. Keterbatasan media serta kemampuan dosen dan mahasiswa dalam menyajikan program WBL, sangat berpengaruh dalam efektivitas pembelajaran berbasis web. Di samping itu, tidak semua mahasiswa tertarik untuk memanfaatkan media web dalam pembelajarannya. Hal ini dapat dilihat dalam penelitian ini bahwa tidak semua mahasiswa menyatakan media web menarik, masih ada mahasiswa yang belum tertarik dengan media web. Oleh karena, media web membutuhkan pengetahuan dan keterampilan khusus dalam mengoperasikannya.

\section{KESIMPULAN DAN SARAN}

Ditinjau dari desain pembelajaran pada aspek GBPP, bahan ajar, dan media ICT online WBL yang dikembangkan dinilai "baik" atau layak digunakan. Hal ini dapat diketahui bahwa semua aspek desain pembelajaran memiliki kategori "sangat valid" $(3,5 \leq \bar{V} \leq 4)$.

Adapun kesimpulan hasil penelitian, penggunaan ICT mempunyai dampak positif terhadap inovasi pembelajaran keterampilan menulis mahasiswa. Dari hasil tes awal dan tes unjuk kerja dalam tatap muka perkuliahan pada kelas eksperimen menunjukkan perbedaan hasil yang signifikan. Dalam kegiatan pembelajaran sebelum digunakan media ICT dan sesudah perlakuan atau penggunaan ICT menunjukkan 
peningkatan hasil belajar yang signifikan. Hal ini terbukti pada tes awal keterampilan menulis kreatif mahasiswa hanya berada di bawah nilai ketuntasan minimal 70 yaitu 31 responden $(86 \%)$ dan hanya 5 responden $(14 \%)$ yang berada di atas nilai keterampilan minimal. Sedangkan pada tes unjuk kerja dalam tatap muka perkuliahan menunjukkan ada 36 responden (100\%) yang berada di atas nilai keterampilan minimal dan tidak satu orang responden yang berada di bawah nilai keterampilan minimal.

Perbedaan hasil pembelajaran pada kelas eksperimen dengan kelas kontrol membuktikan bahwa ada perbedaan ketuntasan belajar mahasiswa antara pembelajaran menggunakan media ICT dengan pembelajaran tanpa media ICT pada kompetensi menulis kreatif. Hasil penelitian ini membuktikan bahwa salah satu cara yang bisa digunakan dalam meningkatkan kompetensi menulis kreatif mahasiswa adalah dengan memanfaatkan media teknologi informasi dan komunikasi melalui web based learning (WBL) dalam pembelajaran keterampilan menulis.

Berdasarkan hasil penelitian, maka saran kepada dosen/guru agar memanfaatkan media pembelajaran dalam pelaksanaan pembelajaran di kelas. Hasil pembelajaran menulis berbasis media ICT dapat meningkatkan kompetensi mahasiswa menulis kreatif. Hal itu telah teruji melalui penelitian ini. Selanjutnya disarankan kepada pengelola pendidikan agar senantiasa mendorong kepada para dosen/guru, untuk membiasakan diri memanfaatkan media ICT melalui program WBL setiap saat dalam proses pembelajaran.

\section{DAFTAR RUJUKAN}

Arsyad, Azhar. 2006. Media Pembelajaran. Jakarta: RajaGrafindo Persada.

Isjoni. 2007. Pemanfaatan Teknologi Pengajaran: Harapan untuk Indonesia. Yogyakarta: Pustaka Pelajar.

Munir, 2009. Pembelajaran Jarak Jauh Berbasis Teknologi Informasi dan Komunikasi. Bandung: Alfabeta.

Sukmadinata, Nana Syaodih. 2008. Metode Penelitian Pendidikan. Bandung: Remaja Rosdakarya Offset. 